\title{
IMPLEMENTASI KURIKULUM 2013 DINTINJAU DARI KOMPETENSI PEDAGOGIK GURU SMA NEGERI DI KECAMATAN ILIR BARAT 1 PALEMBANG
}

\author{
Binar Azwar Anas Harfian \\ FKIP Universitas Muhammadiyah Palembang, Jl. Jend. A. Yani, 13 Ulu Palembang \\ e-mail: binar@um-palembang.ac.id
}

\begin{abstract}
This study aims to find out the implementation of the Curriculum 2013 in terms of pedagogic competence of biology teachers in SMA Negeri Kecamatan Ilir Barat 1 Palembang. This was a survey study and the data were collected from principals, teachers of biology class XI, and grade XI students of the science program of senior high schools in Ilir Barat 1 Palembang District, that have implemented Curriculum 2013, in the academic year of 2014/2015. The research instruments were questionnaires, interviews, observation guides, and documentation. The data were analyzed by using the qualitative descriptive analysis. The results of the analysis are as follows. Biology teachers' readiness level to implement Curriculum 2013 in terms of pedagogic competence in state senior high schools in Ilir Barat 1 PalembangDistrict is that one teacher is in a very prepared category with a percentage of $83 \%$ and three teachers are in the ready category each having a percentage of $81 \%, 71 \%$, and $71 \%$ subsequently.
\end{abstract}

Keywords: biology teacher pedagogical competence, implementation Curriculum 2013.

\section{PENDAHULUAN}

Kurikulum ialah alat yang harus menjamin bahwa tujuan pendidikan yang ditentukan telah tercapai. Hal ini berarti dalam penyusunan kurikulum, terutama hal penentuan isi bahan pengajaran baik yang menyangkut bidang studi maupun pokok bahasan harus berdasarkan tujuan yang telah ditetapkan, sehingga kurikulum sekolah tersebut dapat dipertanggungjawabkan karena dapat menopang tercapainya tujuan pendidikan. Hubungan antara pendidikan dan kurikulum adalah hubungan tujuan dan isi pendidikan yang saling berkesinambungan untuk mencapai tujuan pendidikan yang menyangkut nilai-nilai, ilmu, teori, kemampuan, praktik dan pembinaan sikap mental (Mulyasa, 2010).
Beberapa kali Indonesia telah mengalami perubahan kurikulum, perubahan tersebut erat kaitannya dengan kemajuan suatu bangsa menuju lebih baik. Perubahan kurikulum 2006 (KTSP) menjadi kurikulum 2013 merupakan upaya pemerintah untuk menyempurnahkan mutu pendidikan di Indonesia. Perubahan kurikulum ini merupakan tuntutan, namun disisi lain perubahan kurikulum juga membutuhkan kesiapan dalam banyak aspek, seperti masalah kemampuan guru, buku pelajaran baru, mekanisme pembelajaran, dan lain sebagainya (Schiro, 2014).

Penyelenggaran kurikulum 2013 secara serentak dilaksanakan pada tahun 2014 pada seluruh sekolah di lingkungan pendidikan dasar, menengah dan atas, namun pada 
kenyataan di lapangan beberapa sekolah masih menggunakan Kurikulum KTSP. Penyebab dari hal tersebut adalah karena kurangnya fasilitas yang mendukung dalam pelaksanaan Kurikulum 2013. Kurikulum 2013 menuntut perubahan pola Teaching Centered Learning (TCL) ke arah Student Centered Learning (SCL), hal ini berarti peserta didik harus didorong untuk memiliki kesadaran yang tinggi dalam dirinya untuk belajar.

Kurikulum dipandang sebagai suatu proses yang mencakup semua kegiatan belajar mengajar dalam rangka mencapai tujuan pendidikan yang merupakan pedoman untuk melaksanakan program pengajaran. Pengajaran terdiri dari komponen-kompenen pendidikan yaitu, peserta didik, guru dan situasi pendidikan. Guru memiliki tugas yang sangat fundamental sebagai pendidik dan pengajar yaitu membantu peserta didik untuk mendapatkan kompetensi dan kapasitasnya masing-masing, selain itu guru sendiri seharusnya memiliki kompetensi yang baik pula dalam proses belajar mengajar. Salah satu upaya pemerintah untuk meningkatkan kompetensi guru ialah dengan diadakannya suatu pelatihan dalam wadah Musyawah Guru Mata Pelajaran (MGMP) guna menunjang setiap kompetensi guru agar tercapainya tujuan pendidikan yang lebih baik.

Menurut Setyarahajoe dan Irtanto (2013), pengertian dasar kompetensi ialah kemampuan dan kecakapan seseorang yang dinyatakan kompeten di bidang tertentu, dimana orang tersebut menguasai kecakapan kerja atau keahlian yang selaras dengan tuntutan di bidang kerjanya. Kompetensi guru merupakan salah satu faktor yang memengaruhi tercapainya tujuan pembelajaran dan pendidikan di sekolah. Kompetensi guru mencerminkan tugas dan kewajiban guru yang harus dilakukan sehubungan dengan arti jabatan guru yang menuntut suatu kompetensi tertentu.

Menurut Mirzagitova dan Akhmetov (2015) seorang guru yang profesional tentu harus memiliki empat kompetensi dasar yaitu kompetensi profesional, kompetensi kepribadian, kompetensi sosial, dan kompetensi pedagogik. Pertama kompetensi pedagogik, artinya kemampuan guru dalam mengelola pembelajaran. Kedua kompetensi profesional, artinya guru harus memiliki pengetahuan yang luas yang akan diajarkan. Ketiga kompetensi kepribadian, artinya sikap kepribadian yang pantas diteladani serta mampu melaksanakan kepemimpinan. Keempat kompetensi sosial, artinya guru harus mampu berinteraksi sosial, baik dengan peserta didik maupun dengan sesama guru.

Kompetensi pedagogik merupakan hal mendasar dalam mengimplementasikan Kurikulum 2013 karena kompetensi ini berhubungan langsung dengan kemampuan guru dalam memahami karakter peserta didik, menemukan strategi pembelajaran yang efektif, mengembangkan bahan ajar, media dan sumber belajar serta melakukan penilaian terhadap pencapaian potensi peserta didik sesuai tuntuan normatif tujuan pendidikan yang diharapkan. Kompetensi ini adalah salah satu kemampuan khas yang harus dimiliki seorang guru dalam mendidik peserta didik yang tidak dapat dimiliki oleh profesi lainnya. Kompetensi pedagogik juga mampu mendorong motivasi belajar peserta didik yang berhubungan dengan bagaimana cara guru untuk mengembangkan pembelajaran sebagai tujuan utama dari penyelenggaraan kegiatan pendidikan (Mirzagitova dan Akhmetov, 2015). Apabila semua kriteria kompetensi pedagogik telah terpenuhi maka dapat dikatakan bahwa guru tersebut telah berhasil dalam mengimplementasikan Kurikulum 2013. 
Kompetensi pedagogik guru biologi yang diteliti yaitu di SMA Negeri sekecamatan Ilir Barat 1, Kota Palembang. Berdasarkan data dari Dinas Pendidikan Kota Palembang, Kecamatan Ilir Barat 1 memiliki paling banyak sekolah menengah atas yang berstatus negeri dibandingkan dengan kecamatan lainnya yaitu sebanyak empat sekolah. Pertimbangan lain yaitu sekolah menengah atas di kecamatan ini memiliki akreditasi yang sama yaitu terakreditasi "A". SMA Negeri di kecamatan Ilir Barat 1 terdiri dari SMA Negeri 1 Palembang, SMA Negeri 2 Palembang, SMA Negeri 10 Palembang, dan SMA Negeri 11 Palembang.

Berdasarkan hasil wawancara terhadap wakil kepala sekolah bagian kurikulum di SMA Negeri se- Kecamatan Ilir Barat 1 Kota Palembang yang telah menerapakan Kurikulum 2013, diperoleh informasi bahwa semua guru telah mendapatkan pelatihan tentang Kurikulum 2013, namun pada saat pelaksanaan guru masih mengalami kesulitan dalam melakukan pendekatan saintifik pada saat proses belajar mengajar. Hal lain yang ditemukan yaitu guru masih kebingungan dalam mengembangkan perangkat pembelajarannya, belum tersedianya buku ajar sebagai buku pegangan siswa, terlebih guru merasa kesulitan mengingat secara mendetail aktivitas masing-masing siswa dalam penilaian sikap dan terkesan kurang objektif. Berdasarkan uraian yang telah dijabarkan, maka tujuan penelitian yang akan dicapai dalam penelitian ini adalah untuk mengetahui implementasi Kurikulum 2013 ditinjau dari kompetensi pedagogik guru biologi di SMA Negeri Kecamatan Ilir Barat 1 Palembang.

\section{METODE PENELITIAN}

Penelitian ini termasuk dalam jenis penelitian survei. Penelitian survei ini difokuskan pada kompetensi pedagogik guru mata pelajaran biologi dalam mengimplementasikan Kurikulum 2013. Penelitian ini tidak melakukan perlakuan apapun terhadap subjek penelitian.

Penelitian ini dilaksanakan pada empat SMA Negeri di Kecamatan Ilir Barat 1 Palembang yang menerapkan Kurikulum 2013 mulai tahun ajaran 2013/2014. Pelaksanaan penelitian dilakukan dari bulan September sampai dengan Desember tahun 2017. Satu bulan pertama untuk melakukan observasi awal, bulan kedua, ketiga, dan keempat digunakan untuk melakukan penelitian dan penulisan laporan.

Populasi dari penelitian adalah guru mata pelajaran biologi kelas XI yang mengimplementasikan Kurikulum 2013 di SMA Negeri di Kecamatan Ilir Barat 1 Palembang yaitu sebanyak tujuh orang guru biologi. Seluruh anggota populasi diteliti dalam penelitian ini. Namun dikarenakan adanya masalah perijinan dari pihak sekolah, maka sampel dari penelitian ini direduksi menjadi empat orang guru biologi kelas XI saja.

Subjek penelitian ini adalah guru mata pelajaran biologi kelas XI yang mengimplementasikan Kurikulum 2013, dengan sumber datanya yaitu Kepala Sekolah dan peserta didik kelas XI MIA. Responden diambil dari empat sekolah tersebut sebagai subjek penelitian untuk memperoleh data yang akurat dan menyeluruh. Jumlah responden yang diambil terdiri dari: kepala sekolah sebanyak empat responden, guru mata pelajaran biologi sebanyak empat responden dan siswa sebanyak 150 responden. Kepala sekolah dijadikan sebagai sumber informan untuk mencocokkan informasi yang disampaikan oleh guru dan pendapat siswa tentang kegiatan pembelajaran.

Data dan informasi kompetensi pedagogik guru dalam mengimplementasikan 
Kurikulum 2013 dikumpulkan menggunakan teknik pengisian angket, observasi, wawancara, dan dokumentasi. Instrumen angket yang dikembangkan terdiri dari dua jenis yaitu angket guru dan angket peserta didik. Angket guru dengan responden guru biologi kelas XI yang bertujuan untuk mengetahui pelaksanaan Kurikulum 2013 dengan indikator kompetensi pedagogik guru dan angket peserta didik dengan responden peserta didik kelas XI yang bertujuan untuk mengetahui pelaksanaan pembelajaran dalam mengimplementasikan kurikulum 2013.

Observasi atau pengamatan yang dilakukan adalah untuk melihat aktivitas guru di kelas dan berfungsi untuk mencocokkan antara jawaban guru di angket dengan kondisi yang sebenarnya. Observasi dilakukan pada saat pembelajaran berlangsung. Observasi dilakukan sebanyak tiga kali untuk masing-masing guru. Observer untuk setiap guru adalah sebanyak dua orang. Observer bertugas untuk mencatat aktivitas guru sesuai dengan lembar observasi guru.

Teknik wawancara dilakukan secara langsung dengan menggunakan lembar wawancara. Butir-butir pertanyaan bertujuan untuk mengungkap apakah Kurikulum 2013 sudah dilaksanakan sesuai dengan aturan yang ditetapkan pemerintah, hambatanhambatan yang dialami, dan hasil yang dicapai oleh siswa. Subjek wawancara adalah kepala sekolah atau waka kurikulum, guru biologi kelas XI dan peserta didik IPA kelas XI

Teknik dokumentasi juga digunakan di dalam penelitian ini. Dokumentasi berupa check list ditujukan untuk mencatat komponen yang sudah ditentukan dengan maksud mengecek keaslian dokumen, kebenaran isi dokumen, relevan tidaknya dokumen dengan tujuan dan masalah penelitian. Data dokumentasi merupakan data sekunder yang akan diperoleh secara bersama-sama dengan data lainnya. Adapun data-data dokumen yang diambil adalah data guru, data peserta didik, silabus mata pelajaran biologi, rencana pelaksanaan pembelajaran (RPP), dan dokumen lain yang berhubungan dengan pelaksanaan Kurikulum 2013.

Teknik analisis data yang digunakan dalam penelitian ini adalah analisis deskriptif kuantitatif dan kualitatif, yaitu dengan mendeskripsikan dan memaknai data dari masing-masing variabel yang dievaluasi baik data kuantitatif maupun kualitatif. Sebelum dianalisis, dilakukan proses kuantifikasi data dari angket selanjutnya data tersebut dianalisis dengan menggunakan statistik deskriptif. Untuk data hasil wawancara dan dokumentasi dianalisis dengan analisis kualitatif. Teknik analisis kualitatif yang digunakan adalah model interaktif dari Miles dan Huberman. Dalam melakukan analisis data ada tiga kegiatan yang dilakukan secara bersamaan, yaitu reduksi data, penyajian data, dan penarikan kesimpulan (Ediger dan Rao, 2010). Ketiga kegiatan ini dilakukan selama dan setelah proses pengumpulan data.

Setiap instrumen yang mendukung penelitian ini memiliki kategori komponen sendiri yang disesuaikan dengan masingmasing aspek yang akan diukurnya. Secara lebih terperinci, berikut ini akan dibahas kriteria penilaian untuk setiap komponen penelitian berdasarkan instrumen penelitian yang digunakan.

Instrumen angket penilaian kompetensi pedagogik guru diisi oleh guru biologi kelas XI SMA Negeri di Kecamatan Ilir Barat 1 Palembang yang menerapkan Kurikulum 2013. Skor tertinggi idealnya adalah 124 dan skor minimum idealnya adalah 34 , dengan mean ideal (Mi) yaitu 79 dan simpangan baku ideal (Sbi) adalah 15,00. Berdasarkan data ini, kriteria penilaian mampu atau 
tidaknya responden untuk ditinjau dari aspek pedagogik disajikan mengimplementasikan Kurikulum 2013 dalam Tabel 1.

Tabel 1. Kriteria Penilaian Kemampuan Guru Ditinjau dari Kompetensi Pedagogik

\begin{tabular}{cl}
\hline Kelompok Skor & \\
\hline $101,5<\mathrm{X}$ & Kangat Baik \\
$86,5<\mathrm{X} \leq 101,5$ & Baik \\
$71,5<\mathrm{X} \leq 86,5$ & Cukup Baik \\
$56,5<\mathrm{X} \leq 71,5$ & Kurang Baik \\
$\mathrm{X} \leq 56,5$ & Sangat Kurang Baik \\
\hline
\end{tabular}

Keterangan: $\mathrm{X}=$ skor responden (adopsi dari Azwar (2014)

$$
\text { pembelajaran yang mendidik; }
$$

\section{HASIL DAN PEMBAHASAN}

Implementasi Kurikulum 2013 menurut Mulyasa (2014) merupakan aktualisasi kurikulum dalam pembelajaran dan pembentukan kompetensi serta karakter peserta didik. Hal tersebut menuntut kemampuan guru dalam menciptakan dan menumbuhkan berbagai kegiatan sesuai dengan rencana yang telah diprogramkan. Kemampuan guru tersebut ada pada kompetensi yang harus dimilikinya yaitu kompetensi pedagogik.

Kompetensi pedagogik adalah kemampuan mengelola pembelajaran peserta didik yang meliputi pemahaman terhadap peserta didik, peracangan, pelaksanaan pembelajaran, evaluasi hasil belajar, dan pengembangan peserta didik untuk mengaktualisasikan berbagai potensi yang dimilikinya (Gay dan Airasian, 2016)

Kompetensi pedagogik yang diteliti meliputi (a) menguasai karakteristik peserta didik dari aspek fisik, moral, spiritual, sosial, kultural, emosional, dan intelektual; (b) menguasai teori belajar dan prinsip-prinsip mengembangkan kurikulum yang terkait dengan mata pelajaran yang diampu; (d) menyelenggarakan pembelajaran yang mendidik; (e) memanfaatkan teknologi informasi dan komunikasi untuk kepentingan pembelajaran; (f) memfasilitasi pengembangan potensi peserta didik untuk mengaktualisasikan berbagai potensi yang dimiliki; (g) berkomunikasi secara efektif, empatik, dan santun dengan peserta didik; (h) menyelenggarakan penilaian dan evaluasi proses dan hasil belajar; (i) memanfaatkan hasil penilaian dan evaluasi untuk kepentingan pembelajaran; dan (j) melakukan tindakan reflektif untuk meningkatkan kualitas pembelajaran. Kompetensi pedagogik guru tersebut diungkap melalui angket, wawancara, dan studi dokumentasi berupa RPP.

Berdasarkan hasil analisis data, kemampuan guru mengimplementasikan Kurikulum 2013 ditinjau dari kompetensi pedagogik di SMA Negeri di Kecamatan Ilir Barat 1 Palembang dapat dilihat pada Gambar 1 . 


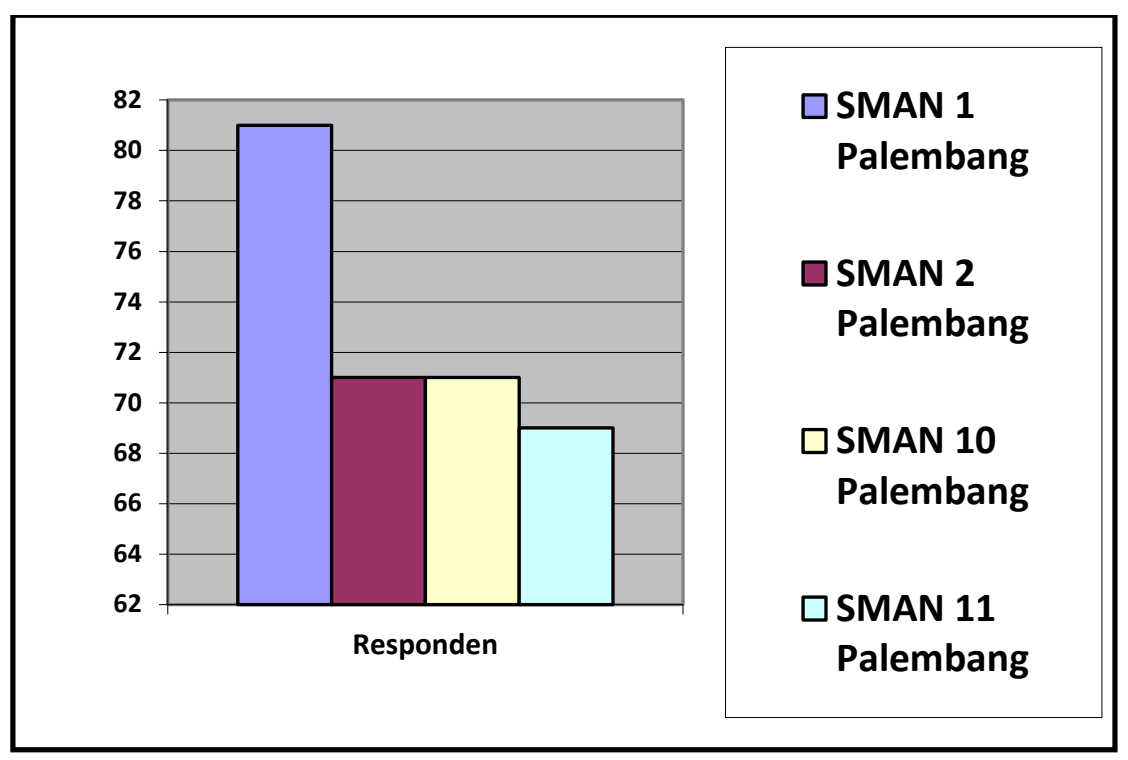

Gambar 1. Diagram Persentase Tingkat Kompetensi Pedagogik Guru Biologi SMA

\section{PEMBAHASAN}

Adapun pembahasan dari hasil yang diperoleh dari masing-masing sekolah akan dijabarkan sebagai berikut.

\section{SMAN 1 Palembang}

Berdasarkan hasil analisis angket dari guru tentang kemampuan guru mengimplementasikan Kurikulum 2013 ditinjau dari kompetensi pedagogik guru biologi pada Gambar 1, total skor yang diperoleh adalah 100 (81\%) dan masuk dalam kategori baik. Skor ini merupakan hasil isian angket yang diberikan kepada guru biologi yang terdiri atas 34 butir soal untuk menilai 10 indikator kompetensi pedagogik guru dalam mengimplementasikan Kurikulum 2013.

Dari 10 indikator tentang kompetensi pedagogik guru, indikator keempat yaitu kemampuan guru dalam menyelenggarakan pembelajaran yang mendidik mendapatkan skor terendah yaitu 12 dari skor maksimal 20. Skor ini diperoleh karena guru jarang menggunakan model pembelajaran seperti yang diharapkan oleh Kurikulum 2013. Berdasarkan wawancara dengan guru diketahui bahwa dalam satu semester, guru menggunakan model pembelajaran yang sesuai dengan Kurikulum 2013 sebanyak 2 kali. Hal ini disebabkan karena menurut pendapat guru, tidak semua materi biologi khususnya pada kelas XI dapat menggunakan model tersebut. Peserta didik juga merasa kurang mampu jika harus menggunakan model pembelajaran yang seperti diharapkan Kurikulum 2013.

Berdasarkan hasil analisis angket dan observasi pada saat pembelajaran didapat bahwa pada indikator keenam yaitu komunikasi dengan peserta didik yang medapatkan persentase tertinggi yaitu $100 \%$. Hal ini sesuai dengan penelitian yang dilakukan oleh Belousa dan Uzulina (2012), indikator komunikasi dengan peserta didik mendapatkan persentase tertinggi yaitu $98 \%$ dengan alasan bahwa guru di MI Ma'arif Ngablak II, Srumbung, Magelang kelas 3 telah mampu memberikan perhatian dan mendengarkan semua pertanyaan dan tanggapan peserta didik, tanpa menginterupsi, kecuali jika diperlukan untuk membantu atau mengklarifikasi pertanyaan atau tanggapan. 


\section{SMAN 2 Palembang}

Berdasarkan hasil analisis angket dari guru tentang kemampuan guru mengimplementasikan Kurikulum 2013 ditinjau dari kompetensi pedagogik guru biologi pada Gambar 1, total skor yang diperoleh adalah 88 (71\%), sehingga masuk dalam kategori baik. Skor ini merupakan hasil isian angket yang diberikan kepada guru biologi yang terdiri atas 34 butir soal untuk menilai 10 indikator kompetensi pedagogik guru dalam mengimplementasikan Kurikulum 2013.

Seperti halnya guru SMAN 1 Palembang, dari 10 indikator tentang kompetensi pedagogik guru, indikator keempat yaitu kemampuan guru dalam menyelenggarakan pembelajaran yang mendidik mendapatkan skor terendah yaitu 9 dari skor maksimal 20. Berdasarkan angket yang diisi guru, dalam satu semester guru hanya sekali menggunakan model pembelajaran Problem Based Learning, Discovery Learning, dan Cooperative Learning, sedangkan model pembelajaran Inquiry hanya sebanyak dua kali dalam satu semester. Hal ini tidak seperti yang diharapkan dalam Kurikulum 2013, yaitu guru mampu menggunakan pendekatan saintifik dalam pembelajaran di kelas. Berdasarkan wawancara terhadap guru, guru merasa sangat kesulitan dalam menerapkan pendekatan saintifik karena peserta didik kelas XI cenderung pasif ketika guru menggunakan pendekatan ini. Peserta didik sangat membutuhkan peran guru dalam pembelajaran di kelas, selain itu meskipun pendekatan saintifik tidak asing pada mata pelajaran biologi, ternyata peserta didik juga masih perlu beradaptasi terhadap pendekatan ini karena di kelas sebelumya guru masih menggunakan pembelajaran konvensional dalam mengajar di kelas.

\section{SMAN 10 Palembang}

E-ISSN :2597-9833

\section{SMAN 10 Palembang}

Berdasarkan hasil analisis angket dari
guru tentang kemampuan mengimplementasikan Kurikulum 2013 ditinjau dari kompetensi pedagogik guru biologi pada Gambar 1, total skor yang diperoleh adalah 88 (71\%), sehingga masuk dalam kategori baik. Skor ini merupakan hasil isian angket yang diberikan kepada guru biologi yang terdiri atas 34 butir soal untuk menilai 10 indikator kompetensi pedagogik guru dalam mengimplementasikan Kurikulum 2013.

Untuk guru SMA Negeri 10 Palembang, dari 10 indikator tentang kompetensi pedagogik guru, indikator keempat yaitu kemampuan guru dalam menyelenggarakan pembelajaran yang mendidik serta indikator keenam tentang kemampuan guru dalam memfasilitasi pengembangan potensi peserta didik untuk mengaktualisasikan berbagai potensi yang dimiliki mendapatkan skor terendah yaitu 12 dari skor maksimal 20 untuk indikator keempat dan skor 22 dari skor maksimal 30 untuk indikator keenam. Skor ini diperoleh berdasarkan angket yang diisi oleh guru . Pada indikator keempat, diketahui bahwa guru pernah 2 kali dalam menggunakan model pembelajaran Problem Based Learning, Inquiry, Discovery Learning, dan Cooperative Learning dalam satu semester.Jumlah ini termasuk kategori jarang dalam menggunakan model pembelajaran seperti yang diharapkan oleh Kurikulum 2013. Berdasarkan wawancara terhadap peserta didik diketahui bahwa guru jarang menggunakan model pembelajaran ini karena guru cenderung fokus terhadap konsep materi yang diajarkan oleh guru. Dalam hal ini, guru lebih banyak ceramah dan memberikan LKS untuk dikerjakan peserta didik. guru memancing pengetahuan peserta didik 
dengan cara memberikan pertanyaan terkait dengan materi yang diajarkan, kemudian dari jawaban peserta didik guru memberikan penjelasan apabila kurang tepat. Indikator keenam juga mendapatkan skor yang rendah. Berdasarkan isian angket yang diisi oleh guru diketahui bahwa guru jarang membimbing peserta didik untuk mengembangkan diri melalui kegiatan ekstrakurikuler, kadangkadang mengembangkan aspek sosial dalam pembelajaran, serta kadang-kadang dalam mengembangkan potensi keterampilan peserta didik dalam pembelajaran yang terdiri atas keterampilan belajar dan keterampilan berpikir.

Berdasarkan hasil analisis angket dan observasi pada saat pembelajaran di SMA Negeri 10 Palembang dapat bahwa pada indikator kesatu yaitu menguasai karakteristik peserta didik dengan rata-rata persentase tertinggi yaitu 94\%. Menurut penelitian Setyarahojoe dan Irtanto (2013), indikator menguasai karakteristik peserta didik mendapatkan persentase tertinggi yaitu $100 \%$ dengan alasan indikator pemahaman karakteristik peserta didik, pelaksanaan pembelajaran, evaluasi hasil belajar dan pengembangan peserta didik untuk mengaktualisasikan potensi yang dimiliki, guru telah memenuhi ke empat indikator yang terlaksana dengan baik.

\section{SMAN 11 Palembang}

Berdasarkan hasil analisis angket dari guru tentang kemampuan guru mengimplementasikan Kurikulum 2013 ditinjau dari kompetensi pedagogik guru biologi pada Gambar 1, total skor yang diperoleh adalah 85 (69\%), sehingga masuk dalam kategori cukup baik. Skor ini merupakan hasil isian angket yang diberikan kepada guru biologi yang terdiri atas 34 butir soal untuk menilai 10 indikator kompetensi pedagogik guru dalam mengimplementasikan Kurikulum 2013.

Dari 10 indikator tentang kompetensi pedagogik guru, indikator keenam yaitu kemampuan guru dalam memfasilitasi pengembangan potensi peserta didik untuk mengaktualisasikan berbagai potensi yang dimiliki mendapatkan skor terendah yaitu 16 dari skor maksimal 30. Berdasarkan angket yang diisi guru, dapat diketahui bahwa guru jarang membimbing peserta didik untuk mengembangkan diri melalui kegiatan esktrakurikuler, serta hanya sekali dalam satu semester untuk membimbing kegiatan penyelidikan dan penelitian. Guru jarang memimbing peserta didik untuk mengembangkan diri melalui kegiatan ekstrakurikuler karena sekolah tidak menyediakan waktu di luar jam pelajaran untuk kegiatan praktikum. Kegiatan praktikum dilakukan pada jam pelajaran sekolah, sehingga untuk kegiatan ekstrakurikuler guru tidak melakukannya.

\section{SIMPULAN DAN SARAN}

Dari hasil analisis dan pembahasan dapat dikemukakan beberapa simpulan sebagai berikut: tingkat kemampuan guru biologi dalam mengimplementasikan Kurikulum 2013 ditinjau dari kompetensi pedagogik di SMA Negeri di kecamatan Ilir Barat 1 kota Palembang yaitu satu orang guru dengan kategori sangat baik, tiga orang guru dengan kategori baik. Untuk kompetensi pedagogik, umumnya indikator penyelenggaraan pembelajaran yang mendidik serta penyelenggaraan penilaian dan evaluasi proses dan hasil belajar mendapatkan hasil yang kurang.

Berdasarkan simpulan, maka saran dalam penelitian ini adalah: (1) untuk guru yang tingkat kemampuannya rendah perlu mendapatkan pelatihan tentang implementasi Kurikulum 2013 dari pemerintah terutama 
Vol. 3, No. 1 : Hal 6-14

pada proses pembelajaran, penilaian, evaluasi proses dan hasil belajar peserta didik; (2) guru perlu selalu meng-update informasiinformasi baru untuk meningkatkan kompetensi pedagogiknya.

\section{RUJUKAN}

Azwar, S. (2014). Penyusunan skala psikologi. Yogyakarta: Pustaka Pelajar.

Belousa, I. \& Uzulina, S. (2012). Teachers view on social and emotional aspect of pedagogical competence, Journal of Social Sciences, 8, 163-169.

Ediger, M. \& Rao, D.B. (2010). Effective school curriculum. New Delhi: Discovery Publishing House.

Gay, L. R., Mills, G. F., \& Airasian, P. (2016). Educational research competencies for analysis and applications ( $9^{\text {th }}$ ed.). London: Pearson Education Ltd.
Mirzagitova, A.L. \& Akhmetov, L.G. (2015). Self-development of pedagogical competence of future teacher. Canadian Center of Science and Educations, 8 (3), 114-121.

Mulyasa. (2010). Implementasi kurikulum tingkat satuan pendidikan. Jakarta: Bumi Aksara.

Mulyasa. (2014). Pengembangan dan implementasi kurikulum 2013. Bandung: Remaja Rosdakarya.

Schiro, M.S. (2014). Curriculum theory conflicting vision and enduring concerns. California: SAGE Publications.

Setyarahajoe, R. \& Irtanto. (2013). The competence of teacher as human resouces at senior high school of kediri city east java province.SAVAP International, 4 (1), 40-49. 